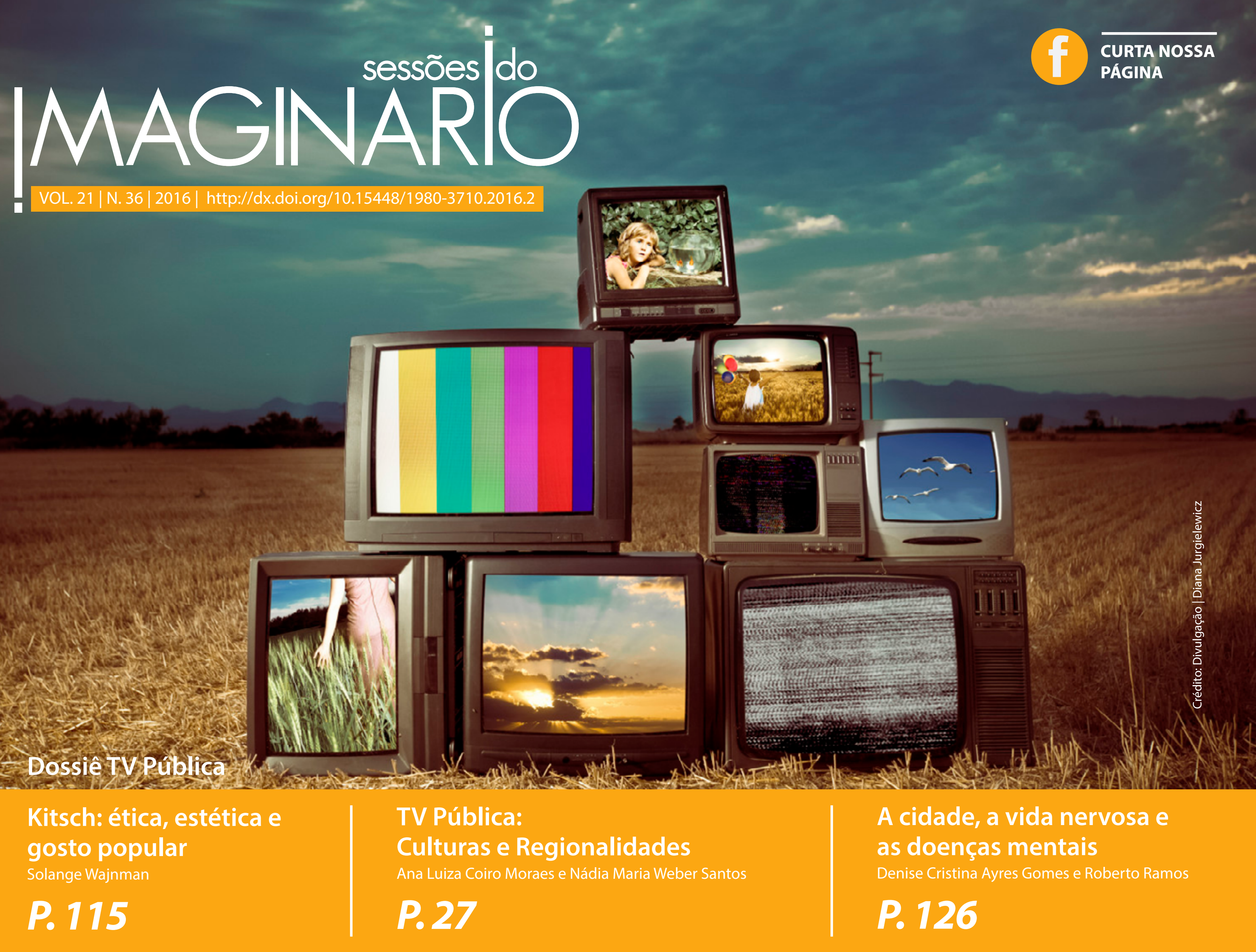




\section{Hora da Notícia: linguagem e resistência}

\author{
Hora da Notícia: language and \\ resistance
}

\section{Resumo}

O objetivo deste artigo é realizar uma reflexão a respeito da linguagem do telejornal Hora da Notícia, dirigido por Vladimir Herzog e veiculado pela TV Cultura de São Paulo nos anos 1970. Pretende-se, a partir de pesquisa bibliográfica, em materiais de arquivo e entrevistas, evidenciar o modo como a linguagem do telejornal dialoga com a linguagem cinematográfica neste programa. Intenta-se, desse modo, pensar as possibilidades de linguagem realizadas num telejornal de uma TV Pública.

\section{Palavras-chave}

Hora da Notícia; Vladimir Herzog; TV Educativa, telejornalismo, linguagem cinematográfica.

\section{Abstract}

This paper aims to think about the relation between the language of TV news and film language, in order to analyse the television news Hora da Notícia, directed by Vladimir Herzog at São Paulo's TV Cultura, in the 70`s. From bibliographical research, archival material and interviews, this paper intends to show how the language of TV news dialogues with the film language in this program. Thus, we intend to think about the possibilities of language in Public TV news.

\section{Keywords}

Hora da Notícia; Vladimir Herzog; educational TV, telejournalism, film language. 


\section{Introdução}

O objetivo deste artigo é compreender a linguagem do telejornal Hora da Notícia veiculado pela TV Cultura de São Paulo, nos anos 1970, como uma forma de resistência. O programa, líder de audiência da emissora na época, divulgou as intenções e atos governamentais, mas, também, iniciou um debate que permitiu à emissora estabelecer um diálogo com a população. Nesse sentido, torna-se necessário refletir sobre o programa a partir das especificidades da linguagem de um telejornal veiculado em uma TV Pública.

Uma dessas especificidades está na própria maneira de compreender o jornalismo dentro de uma TV educativa'. Entendido como um instrumento de diálogo, o programa permitiu que os problemas enfrentados pelos cidadãos, suas sugestões e queixas fossem evidenciados para os governantes. Para pensar as outras especificidades existentes, torna-se necessário abordar as relações existentes entre a linguagem do telejornal e a linguagem cinematográfica a partir do trabalho desenvolvido por Vladimir Herzog.

O primeiro contato de Herzog com o telejornalismo foi em 1963, como redator e secretário do telejornal Show de Notícias da TV Excelsior. A partir dessa experiência, foi para Londres em 1965, contratado como produtor e locutor do Serviço Brasileiro da BBC e, também, aprimorou seus estudos de televisão e cinema ao cursar, com uma bolsa de estudos cedida pelo governo inglês, o Film and Television Course for Overseas Students, no Centro de Televisão da BBC. Essa bolsa, concedida para Herzog e Fernando Pacheco Jordão, só se tornou possível por causa de uma carta de apresentação da TV Cultura em que manifestava a intenção de contratá-los quando estivessem de volta ao país. No entanto, a TV
Cultura não cumpriu o prometido e, de volta ao Brasil, em 1968, Herzog foi contratado como editor de cultura da revista Visão, cargo que exerceu durante cinco anos.

\section{O telejornalismo e o diálogo com a população}

Em 1975, o então governador de São Paulo, Egydio Martins, tinha o objetivo de fazer várias mudanças em seu governo, entre elas, contratou um grupo de pesquisadores para repensar a comunicação social, o qual apontou defeitos graves na programação da TV Cultura, que incluíam a "indefinição de objetivos, desconhecimento do público a que se dirigia, amadorismo na escolha de temas e na própria realização dos programas e um elitismo que levava a índices de audiência praticamente nulos" (Markun, 2005, p. 76).

O grupo de pesquisadores sugeriu que a TV Cultura reformulasse o telejornalismo e, para isso, utilizasse a programação não apenas para divulgar as intenções e os atos governamentais, mas para abrir um diálogo com a população. Para dirigir essa nova proposta de jornalismo, a emissora indicou o nome de Fernando Pacheco Jordão, que, como estava trabalhando no Globo Repórter, recusou o convite e sugeriu o jornalista Vladimir Herzog para desempenhar a função. A emissora aceitou a indicação e o convidou para assumir o cargo.

No entanto, antes de assumi-lo, em 1975, Herzog encaminhou ao governador, ao secretário de Cultura e ao presidente da Fundação Padre Anchieta um documento intitulado Considerações Gerais sobre a TV Cultu$r a$. Nele, o jornalista propunha uma forma de mudar o rumo do jornalismo na emissora a partir da necessidade de refletir sobre a responsabilidade social que é inerente às práticas do jornalismo em emissoras públicas.
Sob essa perspectiva, o documento indicava algumas características do profissional da comunicação, que dizem respeito ao seu compromisso com a educação e a informação crítica e equilibrada. Destacava, também, o foco no cidadão a partir de padrões apolíticos e não comerciais. Durante o período em que morou em Londres, Herzog já havia manifestado esse compromisso. Numa carta escrita na Inglaterra a amigos brasileiros, Herzog relatou:

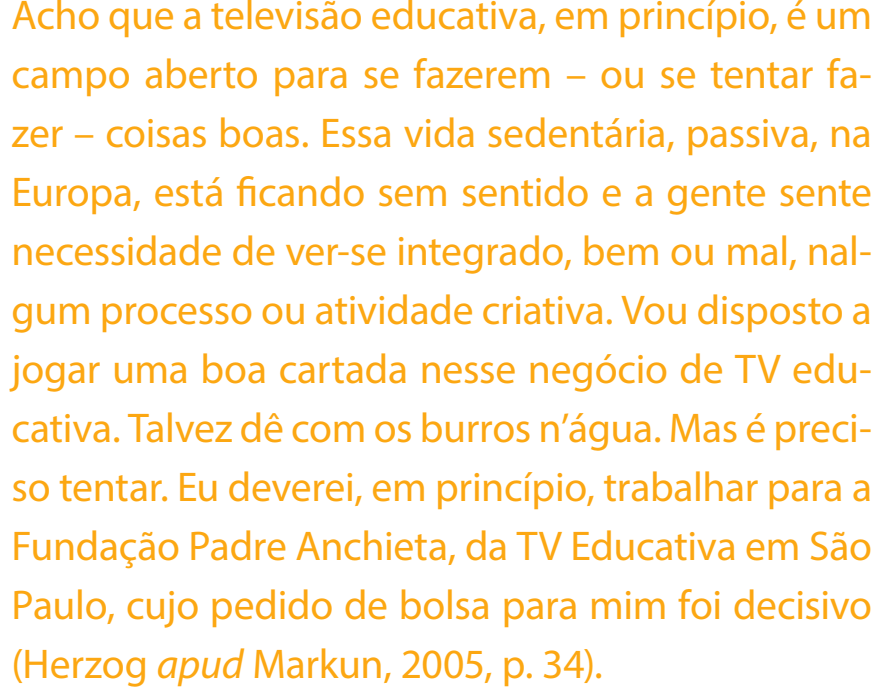

Em suas Considerações, Herzog salienta o direito à educação e à cultura por intermédio das televisões educativas e também destaca a importância de investir recursos profissionais, financeiros e técnicos no setor de jornalismo para a produção, não somente de telejornais diários, mas para vários programas que necessitem, mesmo que indiretamente, de trabalho jornalístico.

De acordo com Leal Filho (1988), a prática do jornalismo proposto por Herzog tornou-se viável, inicialmente, por causa dos baixos índices de audiência da emissora no que diz respeito aos progra- 
mas jornalísticos. No entanto, ao começar a atrair a atenção da audiência por causa da sua singularidade, o telejornal despertou a ira das pessoas que se incomodaram com as denúncias realizadas.

No documento, Herzog sugere, também, duas ações que visavam aumentar a audiência da emissora: a criação de um departamento de publicidade e promoção e a busca de uma nova imagem junto ao público. De acordo com ele:

Jornalismo em rádio e TV deve ser encarado como instrumento de diálogo, e não como um monólogo paternalista. Para isso, é preciso que espelhe os problemas, esperanças, tristezas e angústias das pessoas às quais se dirige. Um telejornal de emissora do governo também pode ser um bom jornal e, para isso, não é preciso 'esquecer' que se trata de emissora do governo. Basta não adotar uma atitude servil (Herzog apud Markun, 2005, p. 78).

O Hora da Notícia como foco de resistência

Nos anos 70, o cenário político brasileiro apresentava-se polarizado: de um lado, a linha dura dos militares no controle do governo federal exercendo um poder quase absoluto proporcionado pelo Ato Institucional $n^{\circ} 5$ (promulgado em 1968) e, por outro, parte da esquerda adotava o caminho da luta armada. Dentro da TV Cultura, a censura vinha de várias frentes: $\mathrm{da}$ própria emissora, do estado e do governo. Pretendia-se que a TV, entre outros meios de comunicação de massa, implantasse projetos de integração nacional.

Mesmo com esse cenário de censura, o telejornalismo da emissora propôs uma "fórmula arrojada" ao suprir a carência de recursos materiais com um traba-

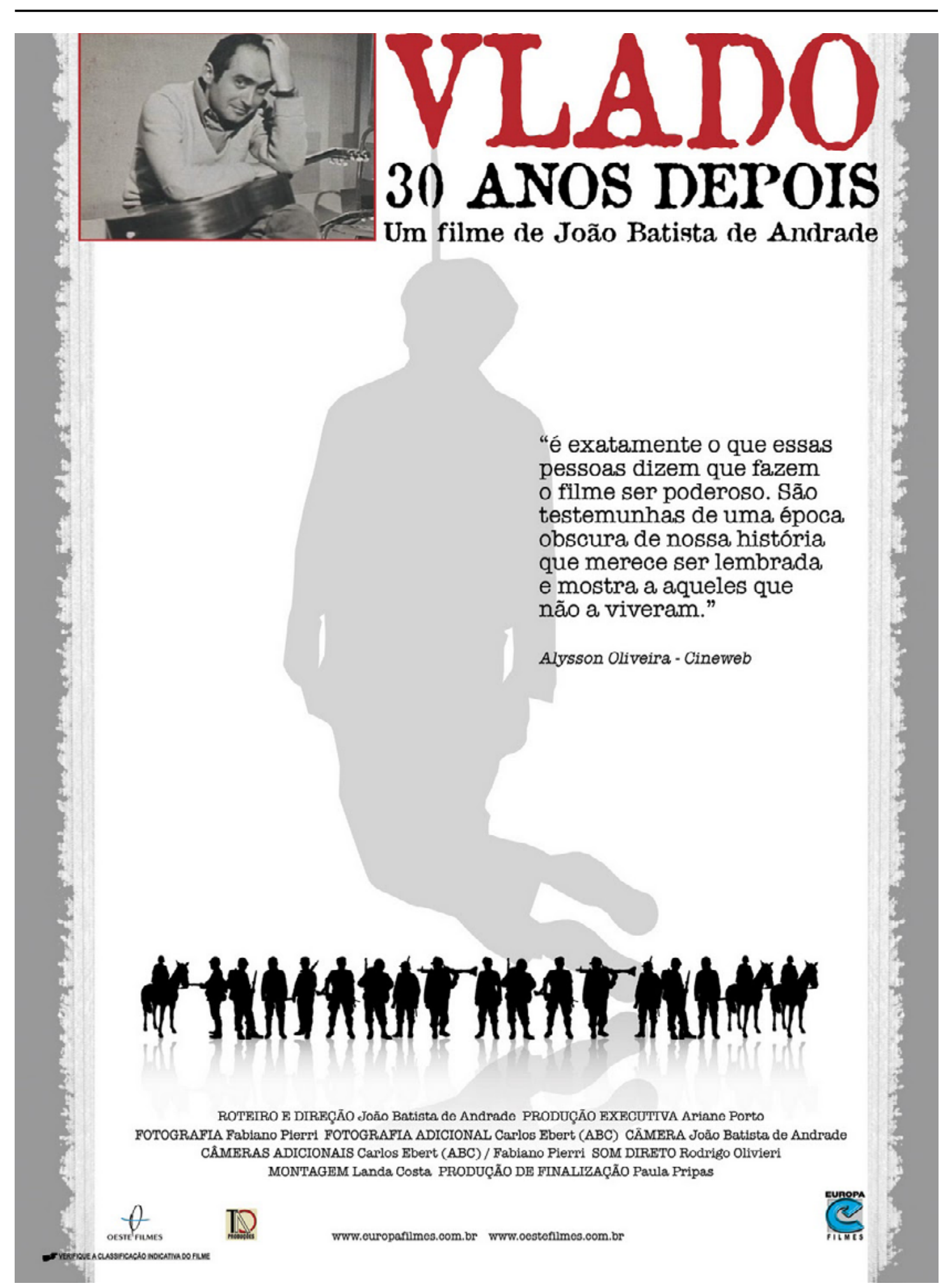

|MAGINARROO 
Iho intenso de pesquisa jornalística, considerado por Leal (1988, p. 54) como "uma prática inusitada para a televisão daquela época: o jornalismo interpretativo"2.

Nesse contexto, em 1972, Fernando Pacheco Jordão foi convidado para organizar o departamento de jornalismo da TV Cultura e, no mesmo ano, assumiu o cargo de chefe de redação e produziu o telejornal Foco na Notícia, uma revista semanal que ia ao ar às 21 horas e apresentava, em 40 minutos, três ou quatro assuntos.

Em 1973, o Foco na Notícia transforma-se num programa diário e tem o nome alterado para Hora da Notícia. Na equipe, Vladimir Herzog como editor e João Batista de Andrade como repórter especial, além dos jornalistas Luis Weiss, Fernando Morais, Anthony de Christo, Marco Antônio, Georges Bordoukan, Narciso Kalili, entre outras pessoas.

Pensado, inicialmente, como um telejornal da hora do almoço, o Hora da Notícia $1^{a}$ edição, com o aumento da audiência, passou a ser veiculado às $21 \mathrm{~h}^{3}$. O programa tinha como objetivo realizar um jornalismo "dinâmico e honesto", que evidenciava tanto os acontecimentos do mundo quanto os da cidade. Para tal, pensava a informação num contexto mais amplo de modo a tornar possível a discussão das causas e dos efeitos do assunto abordado.

No artigo Telejornalismo, a década da tranquilidade, Elizabeth Carvalho (1979) afirma que só foi possível consolidar "o sonho de um telejornalismo diário, dinâmico, inteligente e voltado para a realidade brasileira" (p. 40) a partir de 1970 com a TV Cultura de São Paulo. O Hora da Notícia é um exemplo desse telejornalismo. Sob a responsabilidade do jornalista Fernando Pacheco Jordão, o programa não obedecia a um padrão específico e nem se preocupava

com a forma. O que havia em comum entre todas as partes do telejornal era a preocupação em relacionar todos os assuntos abordados com o telespectador.

O Hora da Notícia enfrentou resistência tanto internamente quanto externamente. O presidente da Fundação Padre Anchieta, na época, José Bonifácio Nogueira, temia tanto a censura quanto a possível influência de Fernando Pacheco Jordão no noticiário. De acordo com João Batista de Andrade (2010)

\begin{abstract}
A visão que eu e Fernando Jordão tínhamos, era de uma democratização da tela e de interesse pelos reais problemas da sociedade, em contraposição a fantasias institucionais e à alienação dos noticiários até aquele momento. Isso implicava, como ocorreu no Hora da Notícia, na quebra de velhos hábitos, busca de uma visão independente e não oficial dos fatos, mudanças nos conceitos de autoridade na informação e uma nova eleição hierárquica da importância dos fatos e assuntos (Andrade, 2010).
\end{abstract}

Por não concordar com a maneira como as notícias eram divulgadas, servindo apenas a determinados interesses e sem caráter jornalístico, conforme pontua Leal (1988), em julho de 1974 diversos funcionários do Hora da Notícia pediram demissão. No entanto, Paulo Markun (2005) ao contrário de Leal, afirma que, em 1974, os jornalistas não pediram demissão, mas foram demitidos da TV Cultura. Nessa época, Herzog recupera sua antiga paixão pelo cinema e parte para o sertão da Bahia em busca de cenários e sobreviventes da Guerra de Canudos com o intuito de fazer um filme. Em 1975, o jornalista, volta para a TV Cultura como diretor do departamento de jornalismo.

\section{O diálogo entre a linguagem do}

telejornal e a linguagem do cinema

Na obra Opovofala:um cineastanaárea dejornalismo da TV Brasileira, João Batista de Andrade (2002) entende a TV Cultura de São Paulo como uma TV alternativa, que seguia, ao mesmo tempo, um caminho independente, popular e crítico. Destaca duas influências marcantes sobre o Hora da Notícia: o surgimento de meios de comunicação que evidenciavam uma discussão ausente na grande imprensa e o trabalho desenvolvido por Vladimir Herzog e outros jornalistas como Luis Weiss, Rodolfo Konder, Zuenir Ventura4. De acordo com o autor, o telejornal estava estruturado da seguinte forma:

Um painel neutro de fundo e, à frente, sentados atrás de uma espécie de balcão, dois apresentadores e, eventualmente, um outro participante um especialista em algum assunto ou comentarista. Isto é, era um programa jornalístico como qualquer outro. Também ali os apresentadores eram tipos com empatia, boas vozes, visível credibilidade. Também ali os apresentadores não eram editores nem escreviam seus textos: eram leitores, intérpretes, intermediários entre a redação, repórteres, redatores, editores e o público. Os dois apresentadores (Fábio Peres e Nemércio Nogueira) eram profissionais super bem preparados e capazes, mas não era bem isso o que importava. Importava era se eles "parecessem" inteligentes e bem informados e passassem bem, se dessem credibilidade ao que diriam aos telespectadores (Andrade, 2002, p. 68). 
De acordo com Andrade (2002), assim como em outros telejornais, notava-se no Hora da Notícia um esquema de poder baseado na estrutura do programa. Dessa maneira, o papel desempenhado pelos apresentadores com sua aparência de cumplicidade, seriedade e sobriedade, somada à leitura dramatizada das notícias, com os gestos, olhares e sorrisos, faziam parte de um script que determinava que o programa estaria sob controle.

No entanto, tanto o poder de filtro dos assuntos a serem veiculados quanto a interpretação estavam centralizados na direção de jornalismo. De acordo com o autor, a equipe desejava mudar os conteúdos da informação e, para isso, enfatizava um jornalismo de descoberta, questionamento e investigação "como um serviço de informação real prestado à sociedade, uma proposta de consciência sobre os fatos" (Andrade, 2002, p. 68). Esse telejornalismo de descoberta perpassava todas as funções do telejornal. Paulo Markun (2005) destaca o papel do repórter cinematográfico:

Naquela época, os repórteres cinematográficos utilizavam uma câmera de cinema 16 milímetros. Cada chassi de filme tinha 400 pés, que permitiam registrar algo como 12 minutos de imagens sonoras. Normalmente, com um chassi desses, eram feitas até três matérias. Ou seja: a margem de erro era mínima - não havia espaço para a passagem em que o repórter aparece diante da câmera, contando parte da história, ou para entrevistas mais longas. Na captação das imagens, os cinegrafistas também não podiam exagerar (Markun, 2005, p. 80).

Ao comparar os scripts dos telejornais feitos antes e durante a passagem de Herzog pela TV Cultura, Paulo
Markun (2005) evidencia que o jornal, sob a direção de Herzog, destacava as manchetes voltadas para a utilidade pública: novas tarifas do transporte público, dia do professor, desidratação infantil. Ao envolver decisões oficiais, o enfoque da notícia era dado às consequências na vida das pessoas. Em relação às notícias internacionais, passaram a ter de duas a cinco laudas. Na interpretação de Markun (2005), esse destaque ao noticiário internacional era dado porque a editoria internacional era a menos visada pela censura. De acordo com o autor, "Vlado interferia diretamente nos scripts, trocando termos que considerava impróprios, buscando sentenças mais claras e compreensíveis e controlando qualquer tentativa de contrabando ideológico" (Markun, 2005, p. 90). Em depoimento ao autor, o jornalista Palmério Dória Vasconcellos, que trabalhou na equipe de reportagem coordenada por Herzog, afirma que:

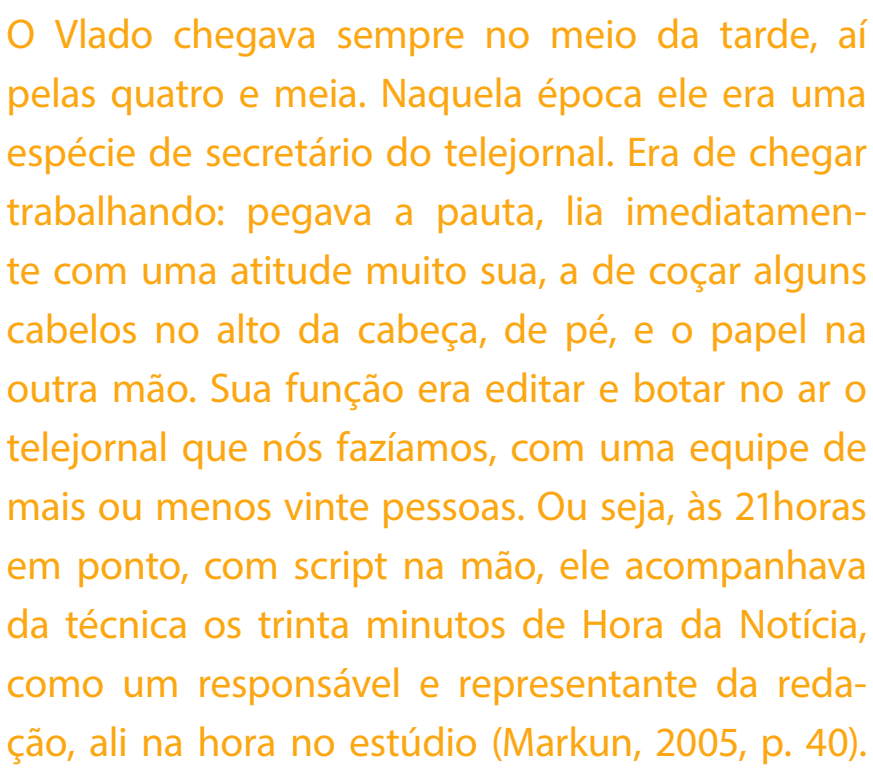
espécie de secretário do telejornal. Era de chegar trabalhando: pegava a pauta, lia imediatamente com uma atitude muito sua, a de coçar alguns cabelos no alto da cabeça, de pé, e o papel na outra mão. Sua função era editar e botar no ar o telejornal que nós fazíamos, com uma equipe de mais ou menos vinte pessoas. Ou seja, às 21 horas em ponto, com script na mão, ele acompanhava da técnica os trinta minutos de Hora da Notícia, como um responsável e representante da redação, ali na hora no estúdio (Markun, 2005, p. 40).

O Hora da Notícia, conforme salienta João Batista de Andrade (2002, p. 64), era, apesar de tudo, o cinema feito para a TV. Eram pequenos documentários de 3,4 e até 7 minutos feitos num só dia por um profissional de cinema que procurava enfrentar as questões da narrativa, da câmera, do significado das palavras e das imagens num filme.

Esse diálogo estabelecido entre as linguagens do cinema e do telejornalismo é evidenciado pelo jornalista Vladimir Herzog antes da sua ida para Londres, nos anos 60. De acordo com Paulo Markun (2005), Herzog foi influenciado pelo cineasta argentino e criador da Escola Documental de Santa Fé, Fernando Birri, de quem foi aluno. $O$ primeiro longa-metragem de Birri, intitulado Tiré Dié (gíria que significa "me dá um dinheiro aí") mostra crianças argentinas pedindo esmola sob o viaduto de uma estrada de ferro. A partir dele, Herzog reflete sobre as potencialidades do documentário:

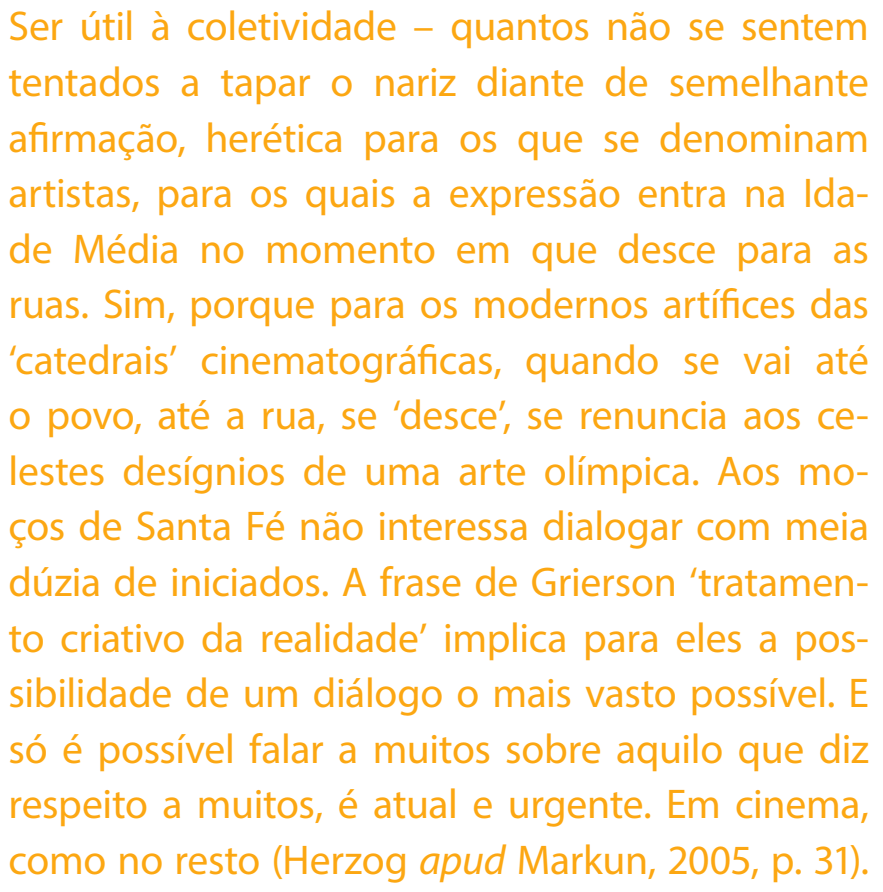
tentados a tapar o nariz diante de semelhante afirmação, herética para os que se denominam artistas, para os quais a expressão entra na Idade Média no momento em que desce para as ruas. Sim, porque para os modernos artífices das 'catedrais' cinematográficas, quando se vai até o povo, até a rua, se 'desce', se renuncia aos celestes desígnios de uma arte olímpica. Aos moços de Santa Fé não interessa dialogar com meia dúzia de iniciados. A frase de Grierson 'tratamento criativo da realidade' implica para eles a possibilidade de um diálogo o mais vasto possível. E só é possível falar a muitos sobre aquilo que diz respeito a muitos, é atual e urgente. Em cinema, como no resto (Herzog apud Markun, 2005, p. 31). 
Uma outra influência cinematográfica para Herzog foi o cinema-verdade. As características desse movimento são evidenciadas por Jean Rouch e Edgar Morin nos anos 60 no filme Chronique d'un été (1961), pensado como um documentário sobre a experiência fílmica. Nele, o realizador e as personagens aparecem em cena discutindo o que e como deve ser filmado, tornando, assim, o próprio filme o acontecimento narrativo central ${ }^{5}$. Desse modo, os elementos que tradicionalmente estariam fora de quadro ou atrás das câmeras são inscritos na imagem e apresentados, debatidos, contestados e questionados. Uma delas é a necessidade de reconhecimento do impacto da presença do realizador sobre a realidade observada.

Para o antropólogo e cineasta Jean Rouch, a câmera deveria assumir uma postura interventiva, participativa e reflexiva. Desse modo, optou por "gerar a realidade" em vez de permitir que ela se desenrolasse passivamente diante dele. Para tal, impulsionava a observação participante de modo a permitir uma interatividade no sentido que seria capaz de precipitar a revelação e a ação da personagem.

No artigo-manifesto Pour un nouveau cinema-verité, publicado em 1960, Edgar Morin exalta a necessidade de retomar as experiências documentais que investem na autenticidade do vivido, que podem ir além das aparências e que entrem "no universo desconhecido do cotidiano" delineando, assim, os princípios que formatariam o seu filme com Rouch. Contudo, estava interessado em explorar uma realização cinematográfica em que os próprios pesquisadores integrassem o grupo social estudado e que essa experiência inscrevesse no filme um movimento que fosse capaz de interrogar o homem através do cinema.
O filme Chronique d'un été apresenta ainda uma outra característica inaugural para a história do cinema documentário: os realizadores exibiram o material já editado às personagens e inseriram essa sequência na montagem final. Quase sempre em quadro, expondo suas intenções e pontos de vista, os realizadores atuam: intervêm, conversam, estimulam as discussões, provocam reuniões entre pessoas desconhecidas e provocam-se a si mesmos. Trata-se de um modo de pensar que promove a desestabilização da autoridade narrativa, incorporando o olhar e as ideias do outro ao filme, na medida em que é rodado e/ou montado. Ao retornar as imagens às personagens do filme e problematizar os efeitos da presença dos documentaristas e da câmera os realizadores mostram o filme em estado bruto aos participantes da experiência documental e os convidam a refletir sobre suas impressões sobre a autenticidade das imagens e da veracidade que as personagens emprestaram às suas performances cinematográficas.

A partir dessa influência cinematográfica, nos anos 60, Herzog realiza um curso de documentário com Arne Sucksdorf 6 . Nesse contexto, começou a planejar um documentário sobre a guerra de Canudos e Antônio Conselheiro. No entanto, foi assassinado antes de iniciar as filmagens. Seu primeiro trabalho, criado a partir de um diálogo com o cinema-verdade, foi o curta-metragem Marimbás. Produzido em 1963, o filme retrata o modo de viver de pessoas que viviam das sobras retiradas das limpezas das redes e deixadas na praia pelos pescadores de Copacabana.

Ainda nos anos 60, Herzog trabalhou como diretor de produção do filme Viramundo, de Geraldo Sarno. No entanto, ao ter o seu nome incluído num relatório do Departamento de Ordem Política e So- cial de 1965, por ser considerado um profissional de imprensa que "aberta ou veladamente, se mostram contrários ao Movimento Revolucionário", entrega o cargo para Sérgio Muniz e embarca para a Inglaterra.

Para tornar possível a aproximação entre os interesses da emissora e as necessidades da população, o Hora da Notícia, sob o comando de Vladimir Herzog, abordava assuntos de ligação direta com o telespectador e começava com manchetes a respeito de assuntos de utilidade pública. Quando a notícia envolvia decisões oficiais, o enfoque era dado para as consequências dessas decisões na vida das pessoas. Em 1975, ao assumir a direção do telejornalismo da TV Cultura, Vladimir Herzog vê a possibilidade de colocar em prática a ideia de responsabilidade social inerente às práticas do jornalismo em emissoras públicas.

Fernando Pacheco Jordão costuma ressaltar em suas entrevistas que uma das maiores preocupações de Herzog era fazer um telejornal em que a informação não fosse apenas aparente, mas uma informação que fosse necessária para o público. No entanto, o sucesso conquistado e a visibilidade dada aos telespectadores desagradavam o governo. 0 Hora da Notícia, apesar dos altos índices de audiência, sofria com a censura não apenas externa por causa da ditadura, mas também interna no que dizia respeito ao conteúdo e ao enfoque das matérias.

Embora Vladimir Herzog acreditasse e propusesse em suas Considerações Gerais sobre a TV Cultura uma série de questões relativas à responsabilidade social do jornalismo na TV, não teve tempo de ver os frutos desse trabalho, pois foi assassinado brutalmente pela ditadura militar no mês seguinte. Sua morte abalou o país inteiro e a reação a ela foi determinante para o início do 
fim da ditadura. José Mindlin afirma, no documentário Vlado 30 anos depois, que a morte de Herzog não foi em vão, pois foi um fator decisivo para a abertura política.

\section{Considerações finais}

Para entender a linguagem do telejornal Hora da Notícia como uma forma de resistência, foi necessário refletir sobre o programa a partir das especificidades da linguagem de um telejornal veiculado em uma TV Pública que tem por objetivo pensar o jornalismo como um serviço público e um bem social. Nesse processo, destacou-se o trabalho da equipe de jornalismo acusada de fazer propaganda comunista em seus noticiários. O Hora da Notícia surge nesse contexto com uma proposta de jornalismo interpretativo em que deveriam ser discutidos não apenas os problemas, mas também as suas causas e os seus efeitos.

Nessa perspectiva, o programa não apenas divulgou os atos e intenções do governo, mas iniciou um debate que permitiu à emissora estabelecer um diálogo com a população. Desse modo, o cidadão comum era convidado a expor os seus problemas para as autoridades. Ao evidenciar os problemas sofridos pelo cidadão, bem como permitir que as queixas, sugestões e apreensões fossem manifestadas aos governantes, o telejornal evidenciou a relação existente entre o conceito de jornalismo voltado para uma TV educativa proposto por Vladimir Herzog e uma proposta estética inovadora para a época em que a linguagem do cinema dialogava com a linguagem do telejornal.

\section{Referências}

ANDRADE, João Batista de. 0 povo fala: um cineasta na área de jornalismo da TV brasileira. São Paulo: SENAC, 2002.

CARVALHO, Elizabeth. Telejornalismo, a década da tranquilidade. In: KEHL, Maria Rita; RIBEIRO, Santuza Naves, CARVALHO, Elizabeth. Anos 70: Televisão. Rio de Janeiro: Europa, 1979.

FUNDAÇÃO PADRE ANCHIETA. Estatuto. São Paulo, 2009. Disponível em: <http://www2.tvcultura.com.br/ fpa/institucional/estatuto-fpa.pdf $>$. Acesso em: 02 set. 2016.

HERZOG, Vladimir. Considerações sobre a TV Cultura. In: MARKUN, Paulo. Meu querido Vlado. Rio de Janeiro: Objetiva, 2005.

INSTITUTO VLADIMIR HERZOG. Biografia de um jornalista. Disponível em: <http://vladimirherzog.org/ biografia>. Acesso em: 28 mar. 2014.

LEAL FILHO, Laurindo. Atrás das câmeras: uma relação entre cultura, Estado e televisão. São Paulo: Summus Editorial, 1988

LEANDRO, Paulo Roberto; MEDINA, Cremilda. A arte de tecer o presente (o jornalismo interpretativo). São Paulo: Media, 1973.

MARKUN, Paulo. Meu querido Vlado. Rio de Janeiro: Objetiva, 2005.
MORIN, Edgar. Pour un nouveau cinéma verité. France-Observateur, junho, 1960.

\section{Referências audiovisuais}

ANDRADE, João Batista de; PORTO, Ariane. Vlado - 30 anos depois. Direção de João Batista de Andrade, produção de Ariane Porto. Brasil, 2005. 85 min.

HERZOG, Vladimir. Marimbás. [Filme-vídeo]. Direção de Vladimir Herzog. Brasil, 1963. 11 min.

Notas

1 Doutora em Filosofia pela Universidade do Porto, Portugal. Pós-doutoranda, professora colaboradora e bolsista CAPES do programa de mestrado em Comunicação no Centro de Educação, Comunicação e Artes da Universidade Estadual de Londrina (Rodovia Celso Garcia Cid, PR 445, km 380, Campus Universitário - Portal de Versalhes III, Londrina/PR, CEP: 86051-980). E-mail: oliveira.or.anapaula@gmail.com

2 A TV Cultura de São Paulo é parte constituinte da Fundação Padre Anchieta - Centro Paulista de Rádio e TV Educativas. No estatuto da emissora, define-se como "pessoa jurídica de direito privado, sem fins lucrativos, com autonomia jurídica, administrativa e financeira e plena gestão dos seus bens e recursos, rege-se por seus atos constitutivos e por este Estatuto". Tem como uma de suas finalidades promover atividades culturais e educativas através da televisão, do rádio e de outras mídias. (Cf. http://www2.tvcultura.com.br/ fpa/institucional/estatuto-fpa.pdf). 
3 De acordo com Cremilda Medina e Paulo Roberto Leandro, o jornalismo interpretativo é 'o esforço de determinar o sentido de um fato, através da rede de forças que atuam nele - não a atitude de valoração desse fato ou de seu sentido, como se faz um jornalismo opinativo' (Leandro; Medina, 1973, p. 15-16).

4 "O Hora da Notícia elevava instantaneamente a audiência da TV às 9 h00 da noite, quando entrava no ar, passando de praticamente zero para números como $3 \%$ ou $4 \%$, o que podia ser classificado como sucesso" (Andrade, 2002, p. 63).

50 autor cita os seguintes veículos de informação: o jornal Amanhã de 1966, Movimento, Opinião e Pasquim, entre outros jornais independentes. No rádio, o aparecimento de programas jornalísticos ligados às questões urbanas evidenciavam os problemas de estrutura e os problemas sociais.

6 Considerado um filme de improviso realizado em forma de psicodrama, Chronique d'un été é o filme inaugural do cinema-verdade e, pela primeira vez na história do cinema documentário, um filme utiliza de um método interativo para construir a sua narrativa.

7 O cineasta sueco Arne Edvard Sucksdorff (1917-2001) foi enviado pela UNESCO ao Rio de Janeiro para ministrar um curso de cinema, patrocinado pelo Ministério das Relações Exteriores, com duração de cinco meses. 